\title{
Ghanaian Female Immigrant Entrepreneurs in Canada: Experiences, Challenges, and Coping Strategies
}

\author{
Amos Nkrumah \\ Department of Sociology, University of Saskatchewan, Saskatoon, Canada \\ Email: amn725@mail.usask.ca
}

How to cite this paper: Nkrumah, A. (2016) Ghanaian Female Immigrant Entrepreneurs in Canada: Experiences, Challenges, and Coping Strategies. Open Journal of Social Sciences, 4, 59-78.

http://dx.doi.org/10.4236/jss.2016.410005

Received: August 25, 2016

Accepted: October 17, 2016

Published: October 20, 2016

Copyright $\odot 2016$ by author and Scientific Research Publishing Inc. This work is licensed under the Creative Commons Attribution International License (CC BY 4.0).

http://creativecommons.org/licenses/by/4.0/ (c) (i) Open Access

\begin{abstract}
Immigrant women of African descent face series of injustices in the process of integrating into the host society, particularly in the labour market because they are women and minorities. The purpose of this paper is to explore the experiences, challenges, and strategies of these female immigrant entrepreneurs in Canada. Using snowball sampling and in-depth interview, principally these women go into entrepreneurship due to family considerations. Furthermore, there are several injustices that the women face, such as race regarding the colour of skin, and the accented manner they speak English. The study also finds that Ghanaian women entrepreneurs have developed coping strategies through the building of networks, determination, and "faceless" business transactions to overcome the inequalities, and to win and maintain clients and expand their business.
\end{abstract}

\section{Keywords}

Immigrants, Entrepreneurship, Ghanaian, Feminism, Race, Language

\section{Introduction}

Entrepreneurship is one of the pillars of Canada's economy and helps create jobs. Until recently, much of the literature on entrepreneurship focused on men because of cultural and political injustices which have denied women equal representation over the years. In the last two decades, research has shown that women constitute thirty-four percent of the self-employed in Canada, compared to twenty-one percent in 1977 (Hughes, 2003) [1]. However, not much is known about immigrant women entrepreneurs, especially those of African descent, who engage in entrepreneurship as a pathway to survive economically and integrate into the host country. Within the framework 
of social justice, this paper draws on feminist anti-racist theory to explore the experiences of Ghanaian immigrant women entrepreneurs and to document the various injustices regarding gender, race, and language (accent) that these women have experienced in their entrepreneurial activities, as well as strategies they have used to navigate through and overcome these inequalities. Studies on immigrant entrepreneurship in Canada have been gender neutral and mostly focused on immigrant entrepreneurs from Asia because they form the majority in Canada (see Li, 1993 [2]; Wong and Ng, 1998 [3]; Froschauer, 2001 [4]; Smart, 2003 [5]; Wong, 2004 [6]; Ley, 2006 [7]; Chen, 2007 [8]; Kwak, 2013 [9]; Lo and Teixeira, 2015 [10]). The dominance of research on entrepreneurs from Asia is based on the fact that majority of these entrepreneurs entered Canada through the business class category of Canada's immigration system (Ley, 2006) [7]. Ley claims that the Korean and Chinese are associated with high levels of self-employment in Canada. However, there are other immigrants, mainly from SubSaharan Africa, who entered Canada through other categories (economic class, family unification, refugee, and others) but later become entrepreneurs to whom researchers have paid little attention.

Also, research on black entrepreneurs has received little attention, especially in Canada. Even the few studies (see Uneke 1996 [11]; Lo et al. 2000 [12]; Knight 2004 [13]) conducted on self-employed blacks were limited in scope. For example, Uneke's study was a comparative analysis of small business ownership between blacks and Chinese in Toronto, and Knight's research was on black Canadian self-employed women. Although these studies have highlighted some contributions of black entrepreneurs in the Canadian economy, these studies fell short regarding their analyses and discussions of the inequalities that immigrant women from Africa experience and the strategies used to trounce these injustices. Furthermore, studies show that experiences of men and women in the labour market activities are not the same regarding access to paid jobs (promotion, pay) and self-employment (Greenman and Xie, 2008 [14]; Browne and Misra, 2003 [15]). From this perspective, this paper focuses on the experiences of Ghanaian immigrant women of African descent entrepreneurs in Canada. There are some studies conducted on Ghanaian immigrants in Canada on various issues, such as transnational economic and political activities (Owusu, 2000 [16]; 2003 [17]); and settlement trajectories regarding housing, religion, culture, and labour market activities (Mensah, 2005 [18]; 2010 [19]; Mensah and Williams, 2013 [20]). Particularly on Ghanaian women, the works of Wong (2000) [21] and Donkor (2004) [22] have focused on the gender dimension of labour market activities and integration in Canada. This research goes beyond the general labour market activities of Ghanaian immigrant women of African descent and specifically focuses on their entrepreneurial activities. I explore ways in which these women have used entrepreneurship as a response to the various discriminatory practices, such as race, gender, and language that have characterized the Canadian labour market. In this paper, I argue that entrepreneurship has become one of the means for Ghanaian women to participate and integrate into the Canadian labour market and society respectively. I further posit that the covert discrimination and other injustices against minority women require creativity and resiliency to counter 
these inequalities. The paper is organized as follows: an overview of the immigration of Ghanaians to Canada, the definition of immigrant entrepreneurship and its theoretical basis, anti-racist feminist theories on gender, race, and language (accent). A case study of Ghanaian female immigrant entrepreneurs in Western Canada is used to highlight the experiences and coping strategies that the women adopt to succeed and integrate into the Canadian society.

\subsection{Ghanaian Immigration to Canada}

Scholarship shows that the postwar economic boom in the 1960s was one of the important factors that shaped the formation and direction of immigration policy in Canada (Li, 2003 [23]; Kelly and Trebilcock, 2010 [24]). For instance, Kelly and Trebilcock (2010) [24] argue that the firm performance of the Canadian economy after the war led to the admission of immigrants from different ethnic backgrounds. Other studies show that the traditional source of immigration (Western Europe, U.K, and U.S.) decreased, while the non-traditional sources (Asian, African, Caribbean, and other non-European) increased as a result of the postwar era and the adoption of the universal selection system (Li, 2003 [23]; Mensah, 2005 [18]). For instance, Li reports that between 1973 and 1988, the immigrants from Africa to Canada increased from 5 percent to about 7 percent. Ghana is of the African countries that have a sizable number of immigrants in Canada.

Ghanaian immigration to Canada started in the 1960 and 1970 (Peil, 1995) [25]. Ghanaians who migrated during this period were mostly government-sponsored students who came to study and other professionals in the health and education sectors (Mensah, 2010) [19]. The year 1980 saw an increase in the migration of Ghanaians to Canada and other Western and non-Western countries due to unfavourable economic and political conditions at that time. For instance, the Structural Adjustment Program (SAP) in Ghana led to the retrenchment of civil servants, removal of subsidies for health care and social service and the rise of unemployment (Kraus, 1991 [26]; Boafo-Arthur, 1999 [27]). The implementation of these policies brought Ghana's economy to a halt coupled with political instability, which created fear and panic because of false imprisonment, murder, and unauthorized seizure of properties (Opoku-Dapaah, 1993 [28]; Oquaye, 1995 [29]). The deteriorating economic conditions and the uncertain political climate in the 1980 pushed many Ghanaians out of the country to Canada and other Western countries. From 1990 to 2000, the categories of Ghanaians who moved to Canada were students and skilled and unskilled workers (Mensah, 2005) [18]. Statistics Canada showed that Ghanaian population in Canada had increased over the last two decades. The 1996, 2006, 2011 censuses recorded 14, 935; 23,220; and 29,355 Ghanaian immigrants respectively (Statistics Canada, 2006 [30]; Statistics Canada, 2011 [31]). It is vital to note that the status of immigrant at the time partially determined the person's labour market and economic activities. For example, majority of the women in this study entered Canada as sponsored spouses by their husbands who were already in Canada. As a result, their legal entry into the Canadian labour market was not impeded 
because they came as landed immigrants. According to this study, other women who came through the visitors' program needed to wait and get authorization before they were able to enter the labour market legally. However, those who were waiting for their permission to work were providing services to their friends such as hair braiding, clothes sewing to make a living and support their families.

The studies on the labour market regarding the activities of Ghanaian immigrants, though very limited, show that they are engaged in varied kinds of professions. For instance, some are in the education sector as university professors, teachers in other levels of education, nurses, bankers, financial consultants, shipping agents, self-employed traders, and other paid related economic activities (Wong, 2000 [21]; Mensah, 2005 [18]; Mensah and William, 2013 [20]). Some of the Ghanaian immigrant women's entry into the Canadian labour market got delayed because most of them became nursing mothers shortly after arrival and could not cope with the system at that time. Those who were able to cope took part-time jobs to be available to their children (Wong, 2000) [21]. Also, the majority of the nursing mothers were not eligible for Employment Insurance (EI), which required a person to have accumulated six hundred hours of paid employment. In the context of Ghanaian immigrant women, these realities shaped their entrepreneurial path in the Canadian labour market because most of these women had a profession or trade before coming to Canada.

\subsection{The Concept of Entrepreneurship}

The setting up of business or income-generating activities has been documented in sociology. In his analysis of the economic structure of society, as explained in Bechhofer and Elliott (1981) [32], Karl Max used the term "petite bourgeoisie" to describe a stratum of people who are small capitalists, such as shop owners who manage the production, distribution, and exchange of goods and services. Bechhofer and Elliott (1981, 188) [32] further define the petite bourgeoisie as "all men and women who use their capital to take over and establish an enterprise, who invest in it with their labour, supplementing that with the effort of family or kin who may also employ a small number of other people". Over time, different terminologies and concepts such as self-employment and entrepreneurship have been used to describe this same business activity. Aldrich and Waldinger (1990, 112 - 113) [33] define entrepreneurs as "owners and operators of business enterprise which includes self-employed persons who employ family labour and use outsiders". On the other hand, Wayland $(2011,9)$ [34] defines self-employed persons as "individuals who work for themselves in incorporated or unincorporated businesses". Research has differentiated between self-employment and entrepreneurship. For example, Wayland (2011) [34] explains that self-employment denotes a mindset of small-scale business, while entrepreneurship denotes a mindset of creativity, innovation and risk-taking. Although this distinction may seem plausible, it is empirically difficult to use innovation, and creativity to differentiate between a self-employed person and an entrepreneur in that the two concepts involve some degree of innovation and creativity. 
In this vein, I agree with Light and Rosenstein (1995) [35] that all businesses, whether large or small, pose a certain degree of innovation and creativity. For instance, the ability to identify a target market and customers to serve involves innovation and creativity. Furthermore, the two concepts entail a continuum from owners of home-based businesses who have fewer employees to the end of the continuum with operators of multi-million dollar businesses. In this study, the term entrepreneurship is used to describe the economic activities of Ghanaian immigrant women because it's hard to determine a fixed boundary between large and small businesses from the perspective of the participants. In this paper, I define entrepreneurs as business owners (economic activities) who use family labour and outsiders. This is to avoid the ambiguity of the scope of the study and also for flexibility and inclusiveness. The decision to set up a business may vary from person to person based on the circumstances, environment, and location; thus, different theories have been propounded for immigrants' motivation towards entrepreneurship.

\subsection{Immigrant Women Motivation for Entrepreneurship}

Existing studies suggest that in Canada, immigrants, especially visible minorities facing unemployment, are more likely to resort to entrepreneurship because of challenges such as lack of recognition of their foreign credentials, segregated labor markets, and discrimination (Aldrich and Waldinger, 1990 [33]; Li, 2000 [36]; 2003 [23]; Light, 2004 [37]). Particularly, Light argues that immigrant motivation to entrepreneurship is opportunity driven as a result of lack of opportunities and discrimination, which has been labelled as disadvantage theory (2004) [37]. This theory argues that immigrants are pushed into self-employment because of some obstacles that they face, which take in two forms-resource (lack of human capital) and labor market (discrimination) (Light and Rosenstein, 1995 [35]; Brubaker, 2011 [38]; Bohn and Lofstrom, 2013 [39]). Bohn and Lofstrom explain the disadvantage hypothesis further that immigrants are pushed into self-employment at a faster rate when there are punitive or harsh policies at the national level on immigration (2013) [39]. However, there have been other theories about the reasons for immigrants' propensity for entrepreneurship. Personality theorist Gibb (1987) [40] argues that it is one's personality that pushes people into entrepreneurship. However, this proposition does not tell us how other factors, such as culture, shape the individual to become an entrepreneur.

Some researchers theorize that there is a relationship between culture and entrepreneurship (see Hayton, et al., 2002 [41]; Stephan and Uhlaner, 2010 [42]) and that the culture of an individual plays a pivotal role in shaping the person to become an entrepreneur. The influence of culture on entrepreneurial development dates back to the work of Weber (1956) [43], who argued that cultural value (Protestantism) in particular was vital to the development of capitalism and its institutions. Max Weber first emphasized the influence of culture on entrepreneurship and argued that Protestantism encouraged a culture that emphasized individualism and legitimized entrepreneurial ventures and self-reliance; thus, the culture influenced by religion determines a person's 
basic values and beliefs. Also, family culture related to entrepreneurial values influences a person to become an entrepreneur. Hofstede (1991) [44] claims that a person's willingness to engage in entrepreneurship depends on one's family background and that the desire involves cultural transmission through socialization. The transmission of culture from one generation to another is through "teaching and imitation of knowledge, values, and other factors that influence behavior" (Boyd and Richerson, 1985, 2) [45].

Furthermore, Bisin and Verdier (2000) [46] argue that entrepreneurial culture is acquired through upbringing, socialization, and professional experience. They claim that parents with entrepreneurial values prefer their children to choose occupations similar to theirs and, accordingly, try to instill in them the needed human capital. It is important to note that the entrepreneurial mindset is developed within the cultural milieu of a person. From the above discussions, theorizing immigrants' motivation towards entrepreneurship is vast and complex and that no single theory can explain why immigrants go into entrepreneurship. Particularly, to understand the complexities of immigrant women of African descent, entrepreneurial activities, and various inequalities require a feminist anti-racism framework within the context of social justice to discuss these injustices regarding gender, race, and language.

\subsection{Feminism and Anti-Racism Framework}

From a feminist perspective, race characterises domination, inequality, and exclusion. As Dua $(1999,9)$ [47] explained, feminism and anti-racism are approaches that seek to "integrate the way race and gender function together in structuring social inequality". Feminist theorists in this direction examine why particularly black women are "othered" and racialized whereby they suffer in their socioeconomic activities. Some scholars have described this intersectionality of gender and race as "double jeopardy" (Beale, 1979) [48]. Frances was the first to use this concept to describe dual discriminations of racism and sexism that subdue black women. According to Frances, black women suffer all the burdens of prejudice and mistreatment and also bear the additional burden of having to cope with white and black men (1979) [48]. Other studies have advocated for a third jeopardy based on class and a fourth based on sexual orientation (King 1988 [49]; Veenstra 2011 [50]). Other studies argue that people with two or more intersecting disadvantage identities experience distinctive forms of oppression and injustice associated with each of her subordinated identities added together (Smith and Stewart 1983 [51]; Lien 1994 [52]). In this study, the inequalities that Ghanaian immigrant women entrepreneurs faced were gender, race, and language based on the narratives of the participants.

Over the years, women have experienced marginalisation based on the roles that society has assigned to them especially in social and economic domains concerning participation in the labour market, which also affected their earnings (Noonan, 2001 [53]; Budig and England, 2001 [54]). Some gender roles are often society specific; migration can often disrupt gender roles for most migrants. However, Giles (2002) [55] argues 
that the disruption of gender roles in the context of migration is not necessarily emancipatory for women; many immigrant women are forced into low paying jobs they least prefer. Also, immigrant women integration process can be further undermined by race. Race has been described loosely as a social construct that categorizes people based on common history or shared lineage of a group of individuals (Banton, 1998) [56], including characteristics of strength, agility, and courage or skin pigmentation and other physical features (Hier, 2007) [57]. Over the years, scholars have debated over the usage of race as an analytical category in social sciences (Rose and Rose, 2005 [58]; Zong, 2007 [59]). However, there is a consensus that race is a social construct and that the concept of race could be used as an interpretative strategy to analyze everyday social life (Satzewich, 2007) [60]. For instance, Satzewich argues that race is embedded in daily life and serves as one of the organizing principles of everyday life (2007) [60]. The reality of race in every fabric of our society cannot be overemphasized. As Thomas and Thomas (1970) [61] argue, if people define situations as real, they are real in their consequences. The effects of race in our society give some advantages to certain groups while other groups tend to suffer. In Canada, the concept of race has been well documented in literature especially its negative impacts on immigrants' labour market experiences (Li, 2000 [36]; Elabor-Idemudia, 2005 [62]; Zong, 2007 [59]; Satzewich, 2007 [60]). The term race has been changed into what Statistics Canada uses the term "Visible Minority" to describe a person or a group of people who are visibly not part of the majority race, in particular, persons who are non-Caucasian in race or non-white in colour and who do not report being Aboriginal. This categorization has marked out some groups as minority and others as the majority. Research suggests that the categorization has made the minority group more vulnerable in their socio-economic endeavours (Bourhis 2003) [63]. The classification of one's background goes beyond the physical traits and includes the person's language.

In Canada, language is one of the criteria for the assessment for successful immigration, that is, one's ability to read, write, and speak English or French or both. English language as a benchmark for interactions in most countries, especially Canada, has its antecedence in colonialism (Pennycook, 1995 [64]; 1998 [65]). He further argues that the speaking and teaching of English language is a product of colonialism which has created an unequal relationship between English and other languages (1998) [65]. The dominance of English language has persisted even in the post-colonial era on ways of thinking and behaving in everyday living. Immigrants in Canada who are non-native speakers of English struggle to adjust to the language and culture. A person's expression in a language is one thing, and the accented manner of that expression is another. Citizens of Commonwealth countries are noted for the British-modeled education and their command over the English language; however, the accent has become a criterion for speaking. In his study on Sub-Saharan African immigrants in Vancouver, Creese (2011) [66] shows how the immigrants from English-speaking countries struggle to find acceptance because of their "African accent". The above-highlighted evidence demonstrates how vulnerable an immigrant could be because of gender, race, and language in 
participating in the socio-economic activities of the host country. These three interrelating factors put immigrant women entrepreneurs in a vulnerable position where they have to develop certain strategies to circumvent the inequalities in their entrepreneurial activities.

\section{Method of the Study}

To explore the experiences, challenges, and coping strategies of Ghanaian women's entrepreneurial activities in the Canadian prairies, the following research questions were considered. What factors motivated the women to become entrepreneurs? What were their major challenges? How were they able to overcome these challenges and coping strategies they used? To be able to answer these research questions, I employed a qualitative methodology, which puts human agency at the center of its analysis of social relationships. The study used snowball sampling to recruit participants for the research. Snowball sampling according to Neuman and Robson $(2009,138)$ [67], "is a method of identifying and sampling the cases in a network". Snowball sampling is unique because it is respondent-driven sampling where initial participants provide leads for further recruitments of participants (Heckathorn 1997 [68]; Morgan 2008 [69]). Goodman (2011) [70] further explained that snowball sampling provides a convenient method to recruit participants who meet the study criteria. Despite the unique features of the snowball sampling technique, there are some limitations. The technique has been criticized because the researcher has little control over the sampling method and because the initial respondents have a strong impact on the sample (Morgan, 2008) [69]. Also, Atkinson raises the issue of biases of the selected group (2004) [71]. To overcome these limitations, I started with the principal informants who were the leaders of the Ghanaian associations in Calgary, Winnipeg, and Saskatoon and explained to them the subject matter of my research. The leadership from the various cities gave me a list of Ghanaians they know to be entrepreneurs and their contacts after seeking their consent. In order not to let the initial respondents have a high impact in the sampling process, as critics suggest, I screened the initial respondents' referrals to make sure that they fit the research objectives.

This paper came out of my Ph. D. dissertation that focuses on immigrants' entrepreneurship in the Canadian prairies. I selected 15 women, five from each city. The paper used face-to-face in-depth interviews held with 15 Ghanaian immigrant women. This method was chosen to record participants' experiences, knowledge, views, and interpretations of their entrepreneurial activities (Mason, 1996) [72]. The data were collected between January and June 2014 in the selected cities. The venue and time for the interviews were chosen in conjunction with the participants. The interviews were held in the participants' homes and offices. On average, each interview lasted for one hour and forty-five minutes, and all the respondents in the study consented to take part in the research. All the interviews were tape-recorded and transcribed. Themes were developed out of the transcription for analysis and discussion of the study. Table 1 shows the demographic and socio-economic characteristics of the participants. 
Table 1. Socio-economic characteristics of the participants.

\begin{tabular}{|c|c|c|c|c|}
\hline Name* & $\begin{array}{l}\text { Number of } \\
\text { Children }\end{array}$ & $\begin{array}{c}\text { Year of } \\
\text { Immigration }^{\star *}\end{array}$ & $\begin{array}{c}\text { Level of } \\
\text { Education }\end{array}$ & Type of Business \\
\hline Adwoa & 4 & $1996(\mathrm{FS})$ & Elementary & Retail Store (Ethnic goods) \\
\hline Ama & 2 & 2008 (FS) & Bachelor's Degree & Import and Export \\
\hline Rosina & 5 & $1986(\mathrm{FS})$ & Bachelor's Degree & Private Home Care Operator \\
\hline Bee & 3 & $1973(\mathrm{FS})$ & Bachelor's Degree & $\begin{array}{l}\text { Hair Braiding and } \\
\text { Extension }\end{array}$ \\
\hline Beatrice & 3 & 2008 (IND) & $\mathrm{PhD}$ & Private Radio Station \\
\hline Dora & 4 & 1995 (FS) & Master's Degree & $\begin{array}{c}\text { Family Doctor-Private } \\
\text { Practice }\end{array}$ \\
\hline Janet & 3 & 1984 (IND) & Bachelor's Degree & Private Home Care Operator \\
\hline Magret & 4 & $1989(\mathrm{FS})$ & College & Private Home Care Operator \\
\hline Hamdiya & 2 & 2004 (FS) & Bachelor's Degree & Imports-Ethnic Products \\
\hline Rose & 2 & 1970s (FS) & Bachelor's Degree & $\begin{array}{l}\text { Restaurant operator } \\
\text { (ethnic and general) }\end{array}$ \\
\hline Juli & 5 & 2009 (FS) & Elementary & Retail Store (Ethnic goods) \\
\hline Akosua & 2 & $2011(\mathrm{FS})$ & Diploma & Hair Braiding and Extension \\
\hline Afia & 3 & $1993(\mathrm{FS})$ & Master's Degree & Private Home Care Operator \\
\hline Abena & 5 & $1994(\mathrm{FS})$ & Master's Degree & Law firm \\
\hline Akua & 2 & 1967 (FS) & Master's Degree & Interior Design \\
\hline
\end{tabular}

Source: Fieldwork, 2014, ${ }^{\star}$ Pseudonyms, ${ }^{* *}$ FS: Family Sponsored; IND: Independent Class.

\section{Findings and Discussions}

\subsection{Motivation and the Entrepreneurial Activities of Ghanaian Female Immigrant}

The complexities of the Canadian labour market coupled with its high demand for human capital have become an enormous challenge for many visible minority immigrants. Research shows that as a result of reported racial inequality and discrimination, some visible minority immigrants resorted to self-employment (Li, 2000 [36]; Brubaker, 2011 [38]; Bohn and Lofstrom, 2013 [39]). The entrepreneurial path of Ghanaian immigrant women shows some nuances. Principally, the decision and motivation for the women to go into entrepreneurship was the opportunity to make more time for their families, especially their children. According to the findings in Table 1, all women had children and indicated their willingness to sacrifice everything for them. In the narratives below, the participants explain their motivation behind becoming entrepreneurs:

I needed the right balance in life; I needed work-family balance. I needed to be able to set my hours, to be available for my children and family, you know, when needed. I did work in an institution; I was an employee, and that did not work for my lifestyle and my circumstances then (Dora).

To balance life and work is to be self-employed, even though you put in a lot of 
time. When you are working for somebody, you are in a rush, and you don't have time for your children-you drop them off at the Daycare, and you pick them up late, so there is hardly any quality family time right (Ama).

My motivation was being a mum, a career woman, and a domestic woman... to merge these you needed a business that would run itself and still be there for your children (Adwoa).

Some studies have suggested that the obstacles immigrants face in the host society, such as discrimination and racial barriers, block visible minorities' access to the open labour market and drive them to self-employment (Portes and Bach, 1985 [73]; Aldrich and Waldinger, 1990 [33]; Li, 2000 [36]). Li discusses those barriers such as proficiency in official languages and credential devaluation as employment obstacles that push visible minorities to self-employment (2000 [36]). However, the findings of this study suggest that although Ghanaian immigrant women have experienced discrimination or racial challenges, their primary motive for setting up their businesses was influenced by their family, especially their children. As shown in Table 1 , credential devaluation was not a major worry for these women because only two of the interviewees had high school and college education; the rest of the participants had Bachelor degrees, Masters' and $\mathrm{PhDs}$, and parts of their credentials were obtained in various Canadian institutions of higher learning. This finding adds to the conversation on the factors that motivate immigrants to become entrepreneurs, and that motivation to entrepreneurship among immigrant is multifaceted and complex, and that depending on the gender and other socio-economic factors, immigrants' motivation towards entrepreneurship will differ. It is critical to note in this study that the women's motivation for entrepreneurship based on family consideration has its roots in the neoliberal policies that have negatively affected women, particularly immigrant mothers in Western countries. O'Brien Hallstein (2014) [74] argues that work-life balance for immigrants has become skewed where family and child care responsibilities have shifted from public support institution to private. Immigrant women facing the challenge of work-life and family balance, coupled with the huge cost of privatized child care services, choose an option that makes them economically active and at the same time be there for their family, hence self-employment. Although this option seems plausible, it has its own challenges, particularly for minority women, based on gender, race, and accent.

\subsection{Experiences and Challenges}

The challenges that visible minority immigrants face in the Canadian labor market has been well documented in the literature. However, the experiences of visible minority immigrant women, mainly immigrant black women, are less understood. Some studies suggest that the challenges of immigrant women start with immigration policies. Though the point system may appear to be inclusive and objective, it is encoded with racial and gender biases (Satzewich, 2007) [60]. For instance, the majority of visible minority immigrant women enter Canada as either dependent or through specific programs such as the Live-in Caregivers Program (Elabor-Idemudia, 2005) [62]. Entry into 
Canada under these categories has its associated conditions, which make it difficult for these women to settle and adapt to the host country. The challenges that immigrant women confront do not end with immigration policies, but go into their earnings in the labour market. Apart from the common challenges that almost all entrepreneurs face, such as access to market and to both human and financial resources, visible minority women entrepreneurs also face challenges because of their gender, race, and language.

The challenges that Ghanaian immigrant women have experienced fall within the domains of gender, race, and language. Abena, a lawyer in private practice, who has been operating since 2006, explained how her background as a black immigrant woman was thrown in her face in her practice:

I had somebody who told me to my face "gee, you are an immigrant, you are a woman, the judges, you know... it will be hard". This Caucasian I met told me,

"You are an immigrant and a woman; it's going to be hard for you to find acceptance". He told me to my face (laugh).

Abena further explained that even in the courtroom, the issue of accent became evident as some judges and lawyers consistently asked her to repeat herself several times with the excuse that they could not understand her accent. Accent discrimination hasbeen documented in literature in Canada. For instance, Munro (2003) [75] identified three forms of accent discrimination in Canada, which were hiring decisions that consider accent, denial of access to a job based on stereotype, and harassment or ridiculing of one's accent. Phillipson (1992) [76] used the term "Linguicism" to refer to all forms of linguistically related racism. Creese's (2011) [66] study of African migrants in Vancouver showed the difficulties that these immigrants in their settlement process had to face because of the accented manner in which they speak the English language.

Another woman, Afia, who operates a private home with 24 employees, narrated some of her challenges as a minority black woman entrepreneur:

I have a client who asked my case manager how a black woman can own a home. How come there are black workers here? How come it has to be black people... Anytime I entered or 1 left the house, she (the client) would use a word [very derogatory]. My staff never told me, and one day, the staff did tell me, and I said "Actually?" and my staff said "Yeah", anytime you walk in and go out, she says that..."

A home interior designer, Akua explained how her field, which is dominated by men posed an enormous challenge for her as a black woman entrepreneur:

My initial challenge is being black... And, then, for me as a minority business person, being a black female is the other challenge. First and foremost, the field that I'm in is male-dominated; whether you are a black or white woman, that is the first hurdle, to be black in that field, is just unheard of even now. And here is the thing, though...

She further narrated how this discrimination manifested in her banking activities: 
It took two years for me to make a large deposit without the bank staff questioning

it. If I went and made a large deposit, I would go through the wringer' If I sent my staff [Caucasian] with the same amount, there would be no problem just because of the colour of their skin... The bank would ask me, "where did you get this cheque from?" They would call the company that issued the cheque to find out...

Some of these racial issues led to the closure of some of these women's businesses, and that led to some diversion of a different business. Rosina, who came to Canada in 1980 and bought a restaurant from a Caucasian, inherited an extensive list of customers and, a few months after she took over, lost almost all the customers she had inherited. According to Rosina, those who used to call and place orders stopped because of language (accent) and those who came physically realized a change in management, and they stopped coming:

At the beginning of the restaurant business, some of the customers will come, especially the white customers and when they realize that you are black they do not come back again, so we lost most of our customers because of that

Another woman Gifty, who bought a restaurant from a Caucasian, told her story this way:

We had lost a lot of clients because of who we were when we bought the business part of it was the goodwill... we inherited a long list of customers from those people, but as soon as we started and they found out that we are black people, we started losing some of them and sometimes people will call looking for a caterer and, hearing your voice, they said "we will call you later", and that is it. There are times I have delivered food and the kinds of questions they asked me showed some ignorance.

The struggles that these women go through regarding gender, race, and accent are sometimes not blatantly expressed but come in a covert form. Upon the realization of this covert racism, the women developed strategies to make their businesses survive.

\subsection{Coping Strategies of Ghanaian Female Entrepreneurs}

According to the women, the first strategy was to develop resiliency and psychological strength to wade off the racial slurs; secondly, they developed a customer base by riding on the back of social capital and joining business and social-related associations and organizations; some took backstage role of the operation of the business, leaving the front role management of the business to the supposed preferred group (the Caucasians) they have employed; another strategy was using what some of the participants called "faceless approach" in the operation of the business, by winning clients and signing contracts via phone.

In this study, one of the profound strategies that run through all the interviewees' strategies was having resiliency coupled with persistence, initiative, and creativity. The psychological strength to ward off racial discrimination has anchored Ghanaian immi- 
grants emotionally in their entrepreneurial journeys. In recent times, the subject of resiliency has emerged as an important area of inquiry. Studies on resilience have identified specific internal and external protective factors that help people to resist adverse effects or ameliorate the impact of risk and enhance adjustment. Internal protective factors such as positive temperament, self-esteem, sociability, and autonomy are developed by the individual (Greene and Conrad 2002) [77]. External protective factors are the environment and include family bonds, supportive social environments and relationships, and other opportunities for meaningful participation (Greene and Conrad 2002 [77]; Roberts et al. 2002 [78]). This study confirms both the internal and external factors, especially positive temperament (internal) and supportive social environment (external) that Ghanaian female immigrant entrepreneurs have developed to shake off the negative impact of race and accent issues. The supportive social environment found in immigrant communities that come from the social capital they have built provides both material (physical) and non-material (emotional) support in their business operations. The social networks that Ghanaian female immigrant entrepreneurs build with immigrant communities, associations, and other professional bodies serve as social capital for them. To the entrepreneurs, having a resilient attitude is imperative for both personal and business endeavors. Afia, who operates a care home, narrated how she used her sense of humour to handle racial slurs directed at her:

Race, I don't look at it; I don't talk about it; even though it is a challenge. I have clients who hate black people. I said, well, maybe the client should move as I have no choice. I always joke, and I say, 'You know what? When God created me, I guess that the barbeque was well done; that is why I'm black. Bring a knife and cut ourselves; what comes out is red blood. Your blood is not white, and my blood is not black same blood.

For Afia, this attitude had helped her navigate the trajectories of racism, which was a huge challenge for her when she started her business. An accounting firm owner, who had prepared herself psychologically and physically to overcome the issue of race and discrimination, had this to say:

I overcame the challenge of being a minority and the perception and label that a black person cannot perform, so, I tried to learn all the things that will boost my confidence for performance from the very beginning-I know racial challenge is there, but I don't focus on it; that is my mindset

Furthermore, Yaa described her sheer determination to succeed in her business in the face of challenges this way:

One thing that I believe God gave me is the spirit of boldness, and He gave me the tenacity to fight; I never give up; I never give up. It is determination and persistence and also knowing that I can't quit because when I quit, who is going to take care of my family that is there...?

The women's psychological strength to wade off racial issues and discrimination has 
anchored them emotionally in their entrepreneurial journey. Another common strategy that these women develop is having a network that generates and maintains their customer base. Studies show that immigrant entrepreneurs draw on multiple ties and networks for advice, access to credit, and customers (Granovetter, 1985 [79]; Aldrich, 1999 [80]; Chrysostome and Arcand, 2009 [81]). Some of these women use their contacts and network within the immigrant community to generate a customer base. The women entrepreneurs, whose target customers are Ghanaians and other Africans, use immigrant associations to create their customer base by taking part and making contributions to the associations' activities.

Gifty, a restaurant operator, used the Ghanaian association as means to network for customers:

Whenever the association is having an event, I get the chance to cook for them because I'm the only one licensed to cook. So in that regard, I get business, and also, Ghanaians who patronize our business, by word of mouth, tell other people who are non-Ghanaians.

In another vein, entrepreneurs whose target and actual customers are non-Africans have a different strategy for wining and maintaining the customers. Regarding winning customers, I term their strategy "faceless transactions", that is, a process where immigrant entrepreneurs conclude business deals over the phone because of the disadvantage of colour and the advantage of accent. Entrepreneurs who use this strategy are the ones who have acquired the North American accent intentionally or unintentionally. Akua, who migrated to Canada as a child with her parents, has acquired the North American accent and subsequently gained most of her clients over the phone. She narrated the strategy this way:

I learnt very quickly not to go to see people in person. I win them over the phone, and fortunately, I don't have the strong accent, so, as far as they are concerned, they were dealing with a Caucasian or Canadian and by the time we actually meet in person, they are too far down in the interaction to get out. They have committed themselves. They are too far in it.

Another dimension of the "faceless" strategy is that some of the entrepreneurs took on backstage roles in the operation of their business and employed Caucasians to be the face of the enterprise. Also, the contact lines of the entrepreneurs have a North American accented message tone. The coping strategies of immigrant women entrepreneurs demonstrate their determination and creativity to win and maintain clients.

\section{Conclusion}

The integration of immigrants, particularly minorities, in Canada is a very complex process and even more so in the labour market. The process is characterised by injustices that put minorities in a vulnerable state. Research has shown that in Canada, immigrant women, particularly those of visible minority origin suffer the most regarding 
income compared with other immigrants' groups (Li, 2003) [23]. As argued earlier, being a woman and, at the same time, of visible minority status presents a double jeopardy. In this context, the principles of social justice based on fairness, equality, and equitable distribution of resources have eluded this group of women because of their race and gender. Immigrant women of African facing huge social inequalities in their adjustment especially in the labour market devise strategies to overcome these injustices. The purpose of this paper has been to document the lived experiences of immigrant women entrepreneurs of African descent particularly to interrogate the inequalities they encounter in their entrepreneurial activities. In this paper, I have argued that the generalization of immigrants' propensity to entrepreneurship or self-employment varied depending on the target group under investigation. Some of these studies have analytically lumped African and Caribbean immigrants into one group (blacks) (White, 1987) [82]. Although, African and Caribbean immigrants may share common physical traits such as skin colour and historical linkages, the socioeconomic profiles and the cultural and political backgrounds of these groups are different. Also, the existing studies focus less on the gender dimension of immigrants' propensity towards entrepreneurship. This paper has provided that family (children) consideration was imperative in their decision to become entrepreneurs. These women had well-paid jobs with benefits, had recognized credentials (obtained in North American academic institutions), but they left those jobs to set up their businesses to attain work and family life balance. I argue that the neoliberal policies have made immigrant women, especially mothers very vulnerable regarding work and family life balance. Second, the narratives of the women show that the challenges they face in their entrepreneurial activities are centred on gender, race, and accent. It is vital to note that, observing from a distance, Canada represents a country where diversity, tolerance, racial tranquility, and respect for human rights prevail. Racism and other forms of inequalities are perceived as relatively muted because of the multicultural policy and the laws that criminalize the issue of racism (Fleras, 2012) [83]. Despite the tolerance for diversity, a closer observation shows that racism is deeply embedded in Canadian society both in the past and the present (see Zong, 2007 [59]; and Fleras, 2012 [83]). The state and its institutions that are mandated to ensure social justice to all people are characterized by (Zong 2007) [59] covert racism, that is, racial discrimination that comes in disguised and subtle form. It can be argued from the narratives of the participants in this study that the state and its institution did not do enough regarding these problems. Based on this, the women had to develop varied strategies such as positive attitude, networking through immigrant associations, and a "faceless" approach to winning clients or taking the backstage role in the running of the business have kept these women entrepreneurs in business in their adopted countries.

\section{References}

[1] Hughes, K. (2003) Pushed or Pulled? Women's Entry into Self-Employment and Small Business Ownership. Gender, Work and Organization, 10, 433-454.

http://dx.doi.org/10.1111/1468-0432.00205 
[2] Li, P. (1993) Chinese Investment and Business in Canada: Ethnic Entrepreneurship Reconsidered. Pacific Affairs, 66, 219-243. http://dx.doi.org/10.2307/2759368

[3] Wong, L. and Ng, M. (1998) Chinese Immigrant Entrepreneurs in Vancouver: A Case Study of Ethnic Business Development. Canadian Ethnic Studies, 30, 64-85.

[4] Froschauer, K. (2001) East Asian and European Entrepreneur Immigrants' in British Columbia, Canada: Post-Migration Conduct and Pre-Migration Context. Journal of Ethnic and Migration Studies, 27, 225-240. http://dx.doi.org/10.1080/13691830020041589

[5] Smart, J. (2003) Ethnic Entrepreneurship, Transmigration, and Social Integration: An Ethnographic Study of Chinese Restaurant Owners in Rural Western Canada. Urban Anthropology, 32, 311-342.

[6] Wong, L. (2004) Taiwanese Immigrant Entrepreneurs in Canada and Transnational Social Space. International Migration, 42, 113-152. http://dx.doi.org/10.1111/j.0020-7985.2004.00283.x

[7] Ley, D. (2006) Explaining Variations in Business Performance among Immigrant Entrepreneurs in Canada. Journal of Ethnic and Migration Studies, 32, 743-764. http://dx.doi.org/10.1080/13691830600704123

[8] Chen, W. (2007) Spinning Transnational Webs: Ethnic Entrepreneurship and Social Networks in the Internet Age. Unpublished PhD Dissertation, University of Toronto, Toronto.

[9] Kwak, M. (2013) Immigrant Entrepreneurship and the Opportunity Structure of the International Education Industry in Vancouver and Toronto. Asian and Pacific Migration Journal, 22, 547-571. http://dx.doi.org/10.1177/011719681302200405

[10] Lo, L. and Teixeira, C. (2015) Immigrants Doing Business in a Mid-Sized Canadian City: Challenges, Opportunities, and Local Strategies in Kelowna, British Columbia. Change and Growth, 46, 631-653. http://dx.doi.org/10.1111/grow.12103

[11] Uneke, O. (1996) Ethnicity and Small Business Ownership: Contracts Between Blacks and Chinese in Toronto. Work, Employment and Society, 10, 529-548. http://dx.doi.org/10.1177/0950017096103007

[12] Lo, L., Preston, V., Wang, S., Reil, K., Harvey, E. and Siu, B. (2000) Immigrants' Economic Status in Toronto: Rethinking Settlement and Integration Strategies. Working Paper No. 15, Joint Centre of Excellence for Research on Immigration and Settlement, Toronto.

[13] Knight, M. (2004) Black Canadian Self-Employed Women. Canadian Women Studies, 23, 104-110.

[14] Greenman, E. and Yu, X. (2008) Double Jeopardy? The Interaction of Gender and Race on Earnings in the United States. Social Forces, 86, 1217-1244. http://dx.doi.org/10.1353/sof.0.0008

[15] Browne, I. and Misra, J. (2003) The Intersection of Gender and Race in the Labor Market. Annual Review of Sociology, 29, 487-513. http://dx.doi.org/10.1146/annurev.soc.29.010202.100016

[16] Owusu, T. (2003) Transnationalism among African Immigrants in North America: The Case of Ghanaians in Canada. Journal of International Migration and Integration, 4, 395413. http://dx.doi.org/10.1007/s12134-003-1027-x

[17] Owusu, T. (2000) The Role of Ghanaian Immigrant Associations in Toronto, Canada. International Migration Review, 34, 1155-1181. http://dx.doi.org/10.2307/2675978

[18] Mensah, J. (2005) Black Canadians: History, Experiences, Social Conditions. Fernwood Publishing, Manitoba.

[19] Mensah, J. (2010) Black Canadians: History, Experiences, Social Conditions. 2nd Edition, 
Fernwood Publishing, Halifax.

[20] Mensah, J. and Williams, C. (2013) Ghanaian and Somali Immigrants in Toronto's Rental Market: A Comparative Cultural Perspective of Housing Issues and Coping Strategies. Canadian Ethnic Studies, 45, 115-141. http://dx.doi.org/10.1353/ces.2013.0013

[21] Wong, M. (2000) Ghanaian Women in Toronto's Labour Market: Negotiating Gender Roles and Transnational Household Strategies. Canadian Ethnic Studies, 32, 45-74.

[22] Donkor, M. (2004) Looking Back and Looking in: Rethinking Adaptation Strategies of Ghanaian Immigrant Women in Canada. International Journal of Migration and Integration, 5, 33-51. http://dx.doi.org/10.1007/s12134-004-1001-2

[23] Li, P. (2003) Destination Canada: Immigration Debate and Issues. Oxford University Press, Canada.

[24] Kelley, N. and Trebilcock, M. (2010) The Making of the Mosaic: A Historical of Canada Immigration Policy. University of Toronto Press, Toronto.

[25] Peil, M. (1995) Ghanaians Abroad. African Affairs, 94, 345-367.

[26] Kraus, J. (1991) The Struggle over Structural Adjustment in Ghana. Africa Today, 38, 1937.

[27] Boafo-Arthur, K. (1999) Ghana: Structural Adjustment, Democratization and the Politics of Continuity. Africa Studies Review, 42, 41-72. http://dx.doi.org/10.2307/525364

[28] Opoku-Dapaah, E. (1993) Inventory of African Community Groups in Metropolitan Toronto. York Lanes Press Inc., Toronto.

[29] Oquaye, M. (1998) Human Rights and the Transition to Democracy under the PNDC in Ghana. Human Rights Quarterly, 17, 556-573. http://dx.doi.org/10.1353/hrq.1995.0029

[30] Statistics Canada (2006) Census of Population, Statistics Canada Catalogue No. 97562XCB2006006. (Canada, Code1)

[31] Statistics Canada (2011) National Household Survey, Statistics Canada Catalogue No. 99-010X2011028.

[32] Bechhofer, F. and Elliott, B. (1981) The Petite Bourgeoisie Comparative Studies of an Uneasy Stratum. Macmillan, London.

[33] Aldrich, H. and Waldinger, R. (1990) Ethnicity and Entrepreneurship. Annual Review of Sociology, 16, 111-135. http://dx.doi.org/10.1146/annurev.so.16.080190.000551

[34] Wayland, S. (2011) Immigrant Self-Employment and Entrepreneurship in GTA: Literature, Data, and Program Review. Maytree, Toronto.

[35] Light, I. and Rosenstein, C. (1995) Race, Ethnicity, and Entrepreneurship in Urban America. Aldine de Gruyter, New York.

[36] Li, P. (2000) Economic Return of Immigrants' Self-Employment. Canadian Journal of Sociology, 25, 1-34. http://dx.doi.org/10.2307/3341909

[37] Light, I. (2004) The Ethnic Economy. In: Smelser, N. and Swedberg, R., Eds., Handbook of Economic Sociology, Russell Sage Foundation, New York, 650-677.

[38] Brubaker, R. (2011) Economic Crisis, Nationalism, and Politicized Ethnicity. In: Calhoun, C. and Derluguian, G., Eds., The Deepening Crisis: Governance Challenges after Neoliberalism, Social Science Research Council and New York University Press, New York, 93-108. http://dx.doi.org/10.18574/nyu/9780814772805.003.0005

[39] Bohn, S. and Lofstrom, M. (2013) Employment Effects of State Legislation. In: Card, D. and Raphael, S., Eds., Immigration, Poverty, and Socioeconomic Inequality, Sage, Russell, 282314. 
[40] Gibb, A. (1987) Enterprise Culture-Its Meaning and Implication for Education and Training. Journal of European Industrial Training, 11, 1-38. http://dx.doi.org/10.1108/eb043365

[41] Hayton, J., George, G. and Zahra, S. (2002) National Culture and Entrepreneurship: A Review of Behavioral Research. Entrepreneurship Theory and Practice, 26, 33-52.

[42] Stephan, U. and Uhlaner, L. (2010) Performance-Based Verses Socially Supportive Culture: Across-National Study of Descriptive Norms and Entrepreneurship. Journal of International Business Studies, 41, 1347-1364. http://dx.doi.org/10.1057/jibs.2010.14

[43] Weber, M. (1956) The Protestant Ethic and the Spirit of Capitalism. Allen \& Unwin, London.

[44] Hofstede, G. (1991) Cultures and Organization. Sage, Thousand Oaks.

[45] Boyd, R. and Richardson, P. (1985) Culture and the Evolutionary Process. University of Chicago Press, Chicago.

[46] Bisin, A. and Verdier, T. (2000) Beyond the Melting Pot: Cultural Transmission, Marriage, and the Evolution of Ethnic and Religious Traits. Quarterly Journal of Economics, 115, 955-988. http://dx.doi.org/10.1162/003355300554953

[47] Dua, E. (1999) Canadian Anti-Racist Feminist Thought: Scratching the Surface of Racism. In: Dua, E. and Robertson, A., Eds., Scratching the Surface: Canadian, Anti-Racist Feminist Thought, Women's Press, Toronto, 7-31.

[48] Beale, F. (1979) Double Jeopardy: To Be Black and Female. In: Cade, T., Ed., The Black Woman: Anthology, New American Library, New York, 90-100.

[49] King, D. (1988) Multiple Jeopardy, Multiple Consciousnesses: The Context of a Black Feminist Ideology. Signs, 14, 42-72. http://dx.doi.org/10.1086/494491

[50] Veenstra, G. (2011) Race, Gender, Class, and Sexual Orientation: Intersecting Axes of Inequality and Self-Rated Health in Canada. International Journal for Equity in Health, 10, 3. http://dx.doi.org/10.1186/1475-9276-10-3

[51] Smith, A. and Stewart, A. (1983) Approaches to Studying Racism and Sexism in Black Women's Lives. Journal of Social Issues, 39, 1-15. http://dx.doi.org/10.1111/j.1540-4560.1983.tb00151.x

[52] Lien, P. (1994) Ethnicity and Political Participation: A Comparison between Asian and Mexican Americans. Political Behavior, 16, 237-264. http://dx.doi.org/10.1007/BF01498879

[53] Noonan, M. (2001) The Impact of Domestic Work on Men's and Women's Wages. Journal of Marriage and Family, 63, 1134-1145. http://dx.doi.org/10.1111/j.1741-3737.2001.01134.x

[54] Budig, M. and England, P. (2001) The Wage Penalty for Motherhood. American Sociological Review, 66, 204-225. http://dx.doi.org/10.2307/2657415

[55] Giles, W. (2002) Portuguese Women in Toronto: Gender, Immigration and Nationalism. University of Toronto Press, Toronto. http://dx.doi.org/10.3138/9781442678644

[56] Banton, M. (1998) Racial Theories. Cambridge University Press, Cambridge. http://dx.doi.org/10.1017/CBO9780511583407

[57] Hier, S. (2007) Studying Race and Racism in 21st-Century Canada. In: Hierand, S. and Bolaria, S., Eds., Race and Racism in 21st-Century Canada: Continuity, Complexity, and Change, Broadview Press, Toronto, 19-33.

[58] Rose, S. and Rose, H. (2005) Why We Should Give up on Race.

[59] Zong, L. (2007) Recent Mainland Chinese Immigrants and Covert Racism in Canada. In: Hierand, S. and Bolaria, S., Eds., Race and Racism in 21 st-Century Canada: Continuity, Complexity, and Change, Broadview Press, Toronto, 111-129. 
[60] Satzewich, V. (2007) Whiteness Studies: Race, Diversity, and the New Essentialism. In: Hierand, S. and Bolaria, S., Eds., Race and Racism in 21 st-Century Canada: Continuity, Complexity, and Change, Broadview Press, Toronto, 67-84.

[61] Thomas, W. and Thomas, D. (1970) Situation Defined as Real, They Are Real in Their Consequences. In: Stone, G. and Farberman, H., Eds., Social Psychology through Interaction, Ginn-Blaisdell, Waltham, 154-155.

[62] Elabor-Idemudia, P. (2005) Immigrant Integration in Canada: Programs and Challenges. In: James, C., Ed., Possibilities and Imitations: Multicultural Policies and Programs in Canada, Fernwood Books, Halifax, 58-74.

[63] Bourhis, R. (2003) Measuring Ethnocultural Diversity Using the Canadian Census. Canadian Ethnic Studies, 35, 9-32.

[64] Pennycook, A. (1995) English in the World/the World in English. In: Tollefson, J., Ed., Power and Inequality in Language Education, Cambridge University Press, Cambridge, 34-58.

[65] Pennycook, A. (1998) English and the Discourses of Colonialism. Routledge, London.

[66] Creese, G. (2011) Erasing English Language Competency: African Migrant in Vancouver, Canada. International Migration and Integration, 11, 295-313. http://dx.doi.org/10.1007/s12134-010-0139-3

[67] Neuman, L. and Robson, K. (2009) Basics of Social Research: Qualitative and Quantitative Approaches. Pearson, Toronto.

[68] Heckathorn, D. (1997) Respondent-Driven Sampling: A New Approach to the Study of Hidden Populations. Social Problems, 44, 174-199. http://dx.doi.org/10.2307/3096941

[69] Morgan, D. (2008) Snowball Sampling. In: Given, L., Ed., The SAGE Encyclopedia of Qualitative Research Methods, SAGE Publications Inc., Thousand Oaks, 816-817.

[70] Goodman, L. (2011) Comment: On Respondent-Driven Sampling and Snowball Sampling in Hard-to-Reach Populations and Snowball Sampling Not in Hard-to-Reach Populations. Sociological Methodology, 41, 347-353. http://dx.doi.org/10.1111/j.1467-9531.2011.01242.x

[71] Atkinson, R. (2004) The Evidence on the Impact of Gentrification: New Lessons for the Urban Renaissance? European Journal of Housing Policy, 4, 107-131. http://dx.doi.org/10.1080/1461671042000215479

[72] Mason, J. (2006) Mixing Methods in a Qualitative Driven Way. Qualitative Research, 6, 925. http://dx.doi.org/10.1177/1468794106058866

[73] Portes, A. and Bach, R. (1985) Latin Journey. University of California Press, Berkeley.

[74] O’Brien Hallstein, L. (2014) When Neoliberalism Intersects with Post-Second Wave Mothering: Reinforcing Neo-Traditional American Family Configurations and Exacerbating the Post-Second Wave Crisis in Femininity. In: Giles, M.V., Ed., Mothering in the Age of Neoliberalism, Demeter Press, Brandford, 297-314.

[75] Munro, M. (2003) A Primer on Accent Discrimination in the Canadian Context. TESL Canada Journal, 20, 38-51. http://dx.doi.org/10.18806/tesl.v20i2.947

[76] Phillipson, R. (1992) Linguistic Imperialism. Oxford University Press, Oxford.

[77] Greene, R.R. and Conrad, A.P. (2002) Basic Assumptions and Term. In: Greene, R.R., Ed., Resiliency: An Integrated Approach to Practice, Policy, and Research, NASW Press, Washington DC, 29-62.

[78] Roberts, B.W., Helson, R. and Klohnen, E.C. (2002) Personality Development and Growth in Women across 30 Years: Three Perspectives. Journal of Personality, 70, 79-102.

http://dx.doi.org/10.1111/1467-6494.00179 
[79] Granovetter, M. (1985) Economic Action and Social Structure: The Problem of Embeddedness. American Journal of Sociology, 91, 481-510. http://dx.doi.org/10.1086/228311

[80] Aldrich, H. (1999) Organizations Evolving. Sage, Thousand Oaks.

[81] Chrysostome, E. and Arcand, S. (2009) Survival of Necessity Immigrant Entrepreneurs: An Exploratory Study. Journal of Comparative International Management, 12, 3-29.

[82] White, P. (1987) The Immigrants Experiences in Paris. In: Glebe, G., and O'Loughlin, J., Eds., Foreign Minorities in Continental European Cities, Franz Steiner Verlag, Stuttgart, 184-198.

[83] Augie, F. (2012) Unequal Relations: An Introduction to Race, Ethnic, and Aboriginal Dynamics in Canada. 6th Edition, Pearson Canada Inc., Toronto.

Submit or recommend next manuscript to SCIRP and we will provide best service for you:

Accepting pre-submission inquiries through Email, Facebook, LinkedIn, Twitter, etc.

A wide selection of journals (inclusive of 9 subjects, more than 200 journals)

Providing 24-hour high-quality service

User-friendly online submission system

Fair and swift peer-review system

Efficient typesetting and proofreading procedure

Display of the result of downloads and visits, as well as the number of cited articles

Maximum dissemination of your research work

Submit your manuscript at: http://papersubmission.scirp.org/

Or contact jss@scirp.org 